Marquette University

e-Publications@Marquette

$5-2004$

\title{
Synthesis and reactivity of
}

\section{tricarbonyl(1-methoxycarbonyl-5-phenylpentadienyl)iron(1+) cation}

\author{
Subhabrata Chaudhury \\ Marquette University \\ William Donaldson \\ Marquette University, william.donaldson@marquette.edu \\ Dennis W. Bennett \\ University of Wisconsin - Milwaukee \\ Daniel T. Haworth \\ Marquette University \\ Tasneem Siddiquee \\ University of Wisconsin - Milwaukee
}

See next page for additional authors

Follow this and additional works at: https://epublications.marquette.edu/chem_fac

Part of the Chemistry Commons

\section{Recommended Citation}

Chaudhury, Subhabrata; Donaldson, William; Bennett, Dennis W.; Haworth, Daniel T.; Siddiquee, Tasneem; and Kloss, Jennifer M., "Synthesis and reactivity of tricarbonyl(1-methoxycarbonyl-5-phenylpentadienyl)iron(1+) cation" (2004). Chemistry Faculty Research and Publications. 60.

https://epublications.marquette.edu/chem_fac/60 


\section{Authors}

Subhabrata Chaudhury, William Donaldson, Dennis W. Bennett, Daniel T. Haworth, Tasneem Siddiquee, and Jennifer M. Kloss

This article is available at e-Publications@Marquette: https://epublications.marquette.edu/chem_fac/60 


\title{
Synthesis and reactivity of tricarbonyl (1-methoxycarbonyl-5-phenylpentadienyl)iron $(1+)$ cation ${ }^{2}$
}

\author{
Subhabrata Chaudhury ${ }^{\mathrm{a}}$, William A. Donaldson ${ }^{\mathrm{a}, *}$, Dennis W. Bennett ${ }^{\mathrm{b}}$, \\ Daniel T. Haworth ${ }^{a}$, Tasneem A. Siddiquee ${ }^{b}$, Jennifer M. Kloss ${ }^{b}$ \\ a Department of Chemistry, Marquette University, P.O. Box 1881, Milwaukee, WI 53201-1881, USA \\ ${ }^{\mathrm{b}}$ Department of Chemistry, University of Wisconsin-Milwaukee P.O. Box 413, Milwaukee, WI 53201-0413, USA
}

Received 23 October 2003; accepted 7 January 2004

\begin{abstract}
Tricarbonyl(1-methoxycarbonyl-5-phenylpentadienyl)iron(1+) hexafluorophosphate (7) was prepared in two steps from tricarbonyl(methyl 6-oxo-2,4-hexadienoate)iron. While addition of carbon and heteroatom nucleophiles to 7 generally occurs at the phenyl-substituted dienyl carbon to afford (2,4-dienoate)iron products, the addition of phthalimide proceeded at $\mathrm{C} 2$ to afford a (pentenediyl)iron product (18). Complex 18 was structurally characterized by X-ray diffraction analysis.
\end{abstract}

(c) 2004 Elsevier B.V. All rights reserved.

Keywords: Carbonyl iron complexes; Dienyl; Nucleophilic attack; Crystal structure

\section{Introduction}

While $\left(\eta^{5}\right.$-pentadienyl)iron(1+) cations were first prepared more than 40 years ago [1], the reactivity of these complexes is of continuing interest, particularly for the synthesis of conjugated polyenes [2]. The stereoselectivity and regioselectivity for nucleophilic attack on these cationic complexes is dependent on the nature of the nucleophile. For example, nucleophilic addition of triphenylphosphine to pentadienyl cation 1 proceeds at the unsubstituted terminus to generate $2 E, 4 Z$-dienoate complex 2a [3], while addition of stabilized carbon nucleophiles such as malonate anion proceeds at the internal C2 carbon to afford primarily (pentenediyl)iron complex 3b (Eq. 1) [4]. While the former regioselectivity is attributed to steric interactions in the transition state leading to attack at the unsubstituted carbon, the latter regioselectivity has been rationalized as the result of charge control; that is, the greater partial positive charge

\footnotetext{
Supplementary data associated with this article can be found, in the online version at doi:10.1016/j.jorganchem.2004.01.010.

${ }^{*}$ Corresponding author. Tel.: +414-288-7374; fax: +414-288-7066.

E-mail address: william.donaldson@marquette.edu (W.A. Donaldson).
}

at the $\mathrm{C} 2$ and $\mathrm{C} 4$ pentadienyl carbons of $\mathbf{1}$ directs nucleophilic attack at these sites.

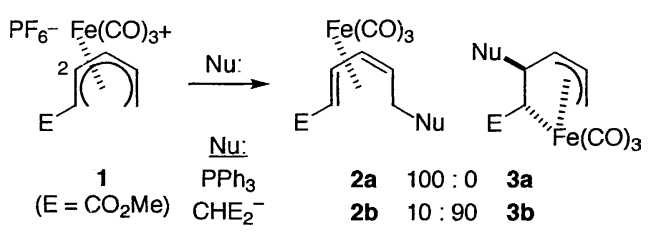

The regioselectivity of nucleophilic addition also depends upon substituents present on the pentadienyl ligand; addition of malonate anion to pentadienyl cation 4 gave predominantly the $Z$-diene product $\mathbf{6 b}$ from attack at the substituted pentadienyl terminus (Eq. 2) [4a]. For this stabilized (pentadienyl)iron cation, nucleophilic attack is predominantly frontier orbital controlled (i.e., attack at the dienyl termini); superimposed on this is the greater stabilization of the partial positive charge at the phenyl substituted dienyl terminus. While there are numerous reports concerning nucleophilic attack on mono-substituted, and 1,2- and 1,4-disubstituted (pentadienyl) $\mathrm{Fe}(\mathrm{CO})_{3}^{+}$cations [5], there are few studies of nucleophilic addition to unsymmetrical 1,5-disubstituted (pentadienyl) $\mathrm{Fe}(\mathrm{CO})_{3}^{+}$cations $[6,7]$. We here report on 
the synthesis and reactivity of a (pentadienyl) $\mathrm{Fe}(\mathrm{CO})_{3}^{+}$ cation 7 bearing both 1-methoxycarbonyl and 5-phenyl substituents.

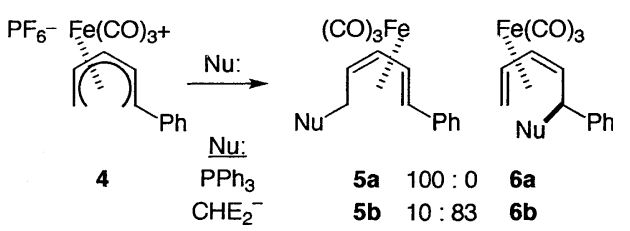

\section{Results}

Reaction of dienal complex $\mathbf{8}$ with phenylmagnesium bromide gave dienol complex 9 (Scheme 1). Dehydration of 9 with $\mathrm{HPF}_{6}$ afforded 7 as a stable yellow solid. While Labassi and Grée [7] have previously used this route for the preparation of 7 , spectral data for this cation were not reported. On the basis of its ${ }^{1} \mathrm{H}$ NMR spectral data, the cation 7 exists, in solution, predominantly as the $c i$ soid structure. In particular, the $\mathrm{H} 2-\mathrm{H} 3$ and $\mathrm{H} 3-\mathrm{H} 4$ couplings (7.1 and $7.3 \mathrm{~Hz}$, respectively) are indicative of their cis relationship. Only a single example of nucleophilic addition to 7 has been reported; reaction of 7 with (trimethylsilyl)alkynyl cerium dichloride gave a (pentenediyl)iron product, albeit in low yield (Scheme 1) [7].

The reaction of 7 with water gave a separable mixture of 9 and two diastereomeric ethers 10a and 10b (Scheme 2). The $\psi$-exo E,E-dienol 9 was identified by comparison of its NMR spectral data with that of the

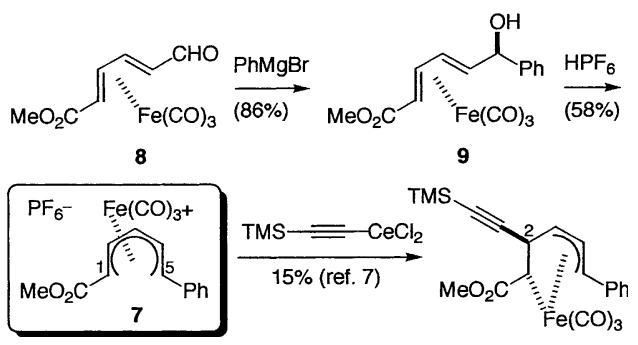

Scheme 1. $\left(\mathrm{E}=\mathrm{CO}_{2} \mathrm{Me}\right)$.

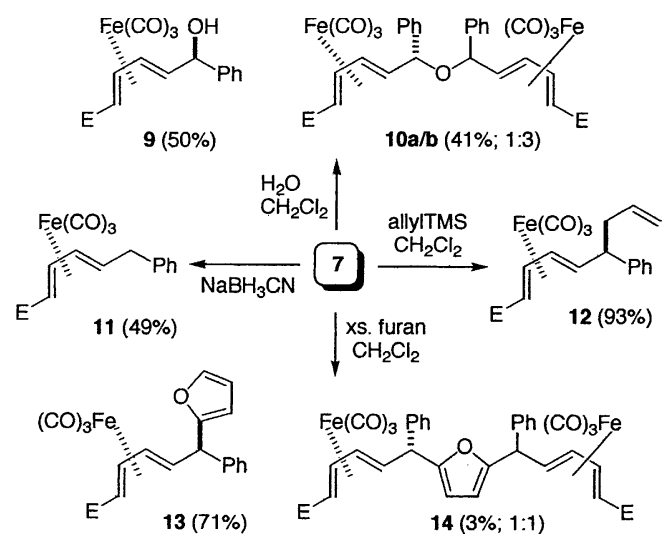

Scheme 2. $\left(\mathrm{E}=\mathrm{CO}_{2} \mathrm{Me}\right)$. complex previously obtained by addition of phenyl Grignard to $\mathbf{8}$ (vide supra). While NMR spectra of dienyl ethers $10 \mathbf{a} / \mathbf{b}$ are similar to that for $\mathbf{9}$, the IR spectra of ethers $\mathbf{1 0 a} / \mathbf{b}$ are devoid of an absorption corresponding to a hydroxyl stretch. In a similar fashion, the reaction of 7 with $\mathrm{NaBH}_{3} \mathrm{CN}$, or allyltrimethylsilane or excess furan gave $E, E$-dienoate products 11-13, respectively (Scheme 2). The reaction of 7 with furan also afforded a small amount of the 2:1 (cation:furan) product $\mathbf{1 4}$ as an inseparable mixture of diastereomers. The structures of products 11-13 were assigned by comparison of their NMR spectral data with that of 9. In particular, signals at ca. $\delta 0.9-1.1$ (d), 5.7-5.9 (dd), and 5.3-5.5 (dd) ppm, in their ${ }^{1} \mathrm{H}$ NMR spectra, and signals at ca. $\delta$ 65-71, 85-87, and 83-84 ppm in their ${ }^{13} \mathrm{C}$ NMR spectra are characteristic for $\mathrm{H} 2$, $\mathrm{H} 3, \mathrm{H} 4$, and $\mathrm{C} 2, \mathrm{C} 3$, and $\mathrm{C} 4$ of $(2 E, 4 E$-dienoate) $\mathrm{Fe}(\mathrm{CO})_{3}$ complexes [2a].

Reaction of 7 with dimethyl malonate or dimethyl methylmalonate anion afforded $E, Z$-diene complexes $\mathbf{1 5}$ or 16, respectively (Scheme 3). The structural assignments of these products are based on their NMR spectral data. In particular, signals at ca. $\delta 2.3-2.4$ (d), 6.0 (dd), and 5.2-5.3 (dd) ppm, in their ${ }^{1} \mathrm{H}$ NMR spectra, and signals at ca. $\delta 94$ and $84-85 \mathrm{ppm}$ in their ${ }^{13} \mathrm{C}$ NMR spectra are characteristic for $\mathrm{H} 2, \mathrm{H} 3, \mathrm{H} 4$, and $\mathrm{C} 3$ and $\mathrm{C} 4$ of $\left(2 E, 4 Z\right.$-dienoate) $\mathrm{Fe}(\mathrm{CO})_{3}$ complexes [8]. Reaction of 7 with triphenylphosphine gave the $E, Z$-dienylphosphonium salt 17 (Scheme 3). The structural assignment for $\mathbf{1 7}$ was made by comparison of its NMR spectral data with that for $\mathbf{1 5}$ and $\mathbf{1 6 .}$

Finally, reaction of 7 with potassium phthalimide gave a single product $\mathbf{1 8}$, proceeding via attack at an internal pentadienyl carbon to afford a crystalline pentenediyl product (Scheme 3). The structural assignment of 18 was based on its NMR spectral data. In particular, the presence of three signals for the metal-carbonyls $(\delta$ $208.9,207.8$, and $202.6 \mathrm{ppm}$ ) is highly characteristic of (pentenediyl) $\mathrm{Fe}(\mathrm{CO})_{3}$ complexes. Additionally, a ${ }^{13} \mathrm{C}$ NMR signal at $\delta 17.4 \mathrm{ppm}$ and a ${ }^{1} \mathrm{H}$ NMR signal at $\delta$ 1.99 (d) ppm are characteristic of a carbon $\sigma$-bonded to iron and its attached proton [2a,4]. The attachment of the phthalimide group at $\mathrm{C} 2$ was tentatively assigned on the basis of the NOESY spectrum of 18; cross-peaks

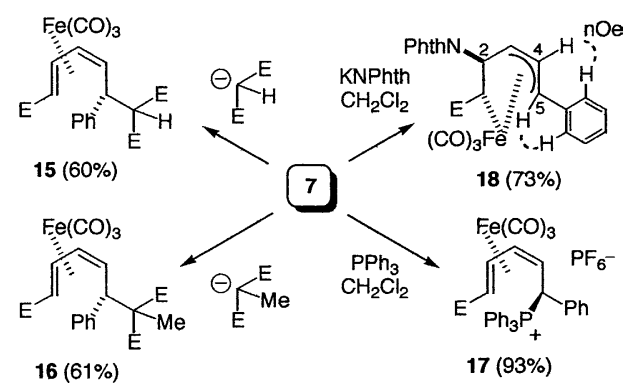

Scheme 3. $\left(\mathrm{E}=\mathrm{CO}_{2} \mathrm{Me}\right)$. 
were observed between the phenyl ortho-protons ( $\delta$ 7.38-7.25 ppm) and the signals for $\mathrm{H} 4$ and $\mathrm{H} 5$ of the $\eta^{3}$ fragment $(\delta 5.48 \mathrm{ppm})$. This tentative assignment was eventually corroborated by single crystal X-ray diffraction analysis (Table 1, Fig. 1). The phthalimide group is situated trans to the (tricarbonyl)iron fragment, implying nucleophilic attack opposite to the metal center. The bond distances and angles for $\mathbf{1 8}$ (Table 2) are in good agreement with those for other (pentenediyl)iron complexes $[4,9]$.

Table 1

Crystallographic data for $\mathbf{1 8}$

$\begin{array}{ll}\text { Empirical formula } & \mathrm{C}_{24} \mathrm{H}_{17} \mathrm{FeNO}_{7} \\ \text { Formula weight } & 487.26 \\ \text { Temperature }(\mathrm{K}) & 293(2) \\ \text { Wavelength }(\AA) & 0.71073 \\ \text { Crystal size }\left(\mathrm{mm}^{3}\right) & 0.43 \times 0.43 \times 0.40 \\ \text { Crystal system } & \text { Monoclinic } \\ \text { Space group } & P 2_{1} / c \\ a(\AA) & 10.949(5) \\ b(\AA) & 13.645(5) \\ c(\AA) & 14.734(5) \\ \beta(\text { deg}) & 97.030(5) \\ V(\AA) & 2184.7(15) \\ Z & 4 \\ D_{\text {calc }}(\mathrm{g} \text { cm } & \\ \text { Absorption coefficient }\left(\mathrm{mm}^{-1}\right) & 1.481 \\ F(000) & 0.737 \\ \text { Range of } \theta\left(^{\circ}\right) & 1004 \\ \text { Reflections collected/unique } & 2.04-24.99 \\ \text { Goodness-of-fit on } F^{2} & 4883 / 3831\left(R_{\text {int }}=0.0244\right) \\ \text { Final } R \text { indices }[I>2 \sigma(I)] & 1.036 \\ R \text { indices (all data) } & R 1=0.0375, w R 2=0.0870 \\ \text { Largest difference peak and } & R 1=0.0548, w R 2=0.0948 \\ \left.\quad \text { hole (e } \AA^{-3}\right) & 0.339 \text { and }-0.310\end{array}$

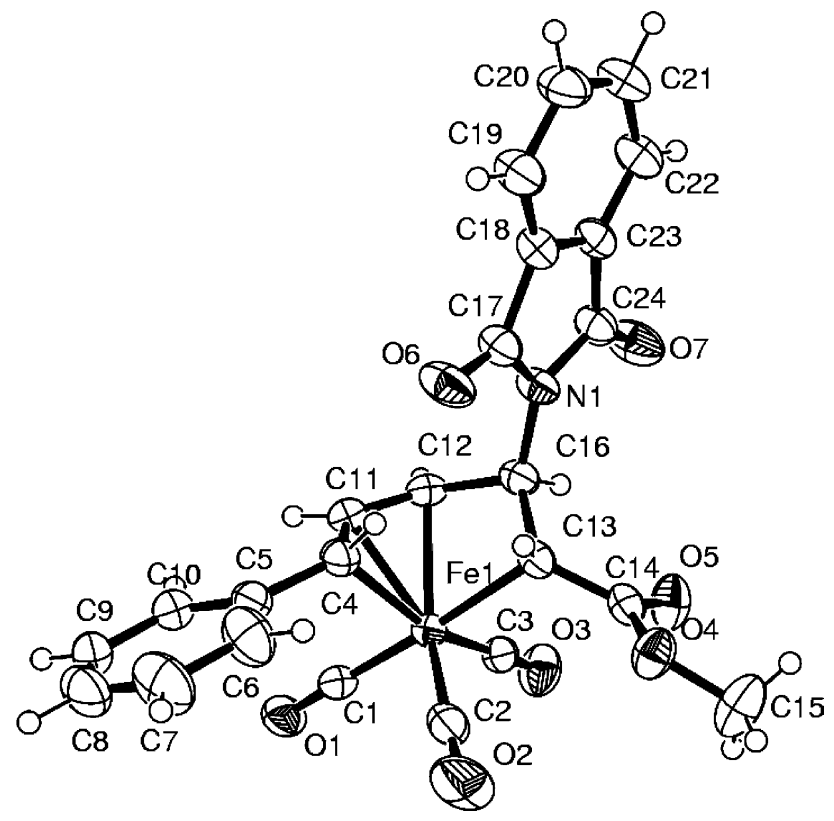

Fig. 1. ORTEP view of $\mathbf{1 8}$ with crystallographic numbering scheme (50\% probability elipsoids).
Table 2

Selected bond distances $(\AA)$ and bond angles $\left(^{\circ}\right)$ (with e.s.d.s in parentheses)

\begin{tabular}{llll}
\hline $\mathrm{Fe}(1)-\mathrm{C}(11)$ & $2.095(3)$ & $\mathrm{C}(13)-\mathrm{Fe}(1)-\mathrm{C}(12)$ & $69.09(10)$ \\
$\mathrm{Fe}(1)-\mathrm{C}(13)$ & $2.115(2)$ & $\mathrm{N}(1)-\mathrm{C}(16)-\mathrm{C}(12)$ & $115.1(2)$ \\
$\mathrm{Fe}(1)-\mathrm{C}(12)$ & $2.150(2)$ & $\mathrm{N}(1)-\mathrm{C}(16)-\mathrm{C}(13)$ & $116.7(2)$ \\
$\mathrm{Fe}(1)-\mathrm{C}(4)$ & $2.179(3)$ & $\mathrm{C}(12)-\mathrm{C}(16)-\mathrm{C}(13)$ & $105.95(19)$ \\
$\mathrm{C}(16)-\mathrm{C}(12)$ & $1.511(4)$ & $\mathrm{C}(11)-\mathrm{C}(12)-\mathrm{C}(16)$ & $127.2(2)$ \\
$\mathrm{C}(16)-\mathrm{C}(13)$ & $1.518(3)$ & $\mathrm{C}(16)-\mathrm{C}(12)-\mathrm{Fe}(1)$ & $89.98(14)$ \\
$\mathrm{C}(12)-\mathrm{C}(11)$ & $1.406(3)$ & $\mathrm{C}(12)-\mathrm{C}(11)-\mathrm{C}(4)$ & $125.8(2)$ \\
$\mathrm{C}(4)-\mathrm{C}(11)$ & $1.409(4)$ & $\mathrm{C}(16)-\mathrm{C}(13)-\mathrm{Fe}(1)$ & $91.13(15)$ \\
\hline
\end{tabular}

\section{Discussion}

In solution, acyclic (pentadienyl) $\mathrm{Fe}(\mathrm{CO})_{3}^{+}$cations are known to exist in an equilibrium between the cisoid form and the corresponding less stable transoid form [10]. In general, reaction of (pentadienyl)iron cations with weak nucleophilies, such as water, proceeds via attack on the less stable, but therefore more reactive, transoid form [11]. Of the two possible transoid isomers of 7 the structure 19A, in which the phenyl substituent is adjacent to the carbon bearing the greatest partial positive charge, is anticipated to be considerably more stabilized than 19B where this carbon is adjacent to the ester substituent (Scheme 4). Formation of the $E, E$ - $\psi$-exo dienol $\mathbf{9}$, from the reaction of 7 , is consistent with attack by a weak nucleophile water on the transoid form 19A. The ether products $\mathbf{1 0 a} / \mathbf{b}$ arise via reaction of the cation 7 with dienol 9 at a competitive rate to reaction with water. Since the cation 7 and therefore the dienol 9 are both racemic mixtures of enantiomers (with respect to coordination of the diene) then two diastereomeric ethers are formed [12]. In a similar fashion, the formation of single products from the addition of the weak nucleophiles allyltrimethylsilane and furan are not surprising, since the regiochemical directing effects of the two substituents present on 7 are "matched" [5c].

For phosphine nucleophilies, attack generally occurs on the more abundant cisoid form of the (pentadienyl)iron cation, and at the less sterically hindered terminus $[3,6 \mathrm{~d}, 13]$. Thus the regiochemical directing effects of the substituents present on 7 are "mismatched" for the addition of phosphines (cf. Eqs. 1 and 2). The product (18) from reaction of $\mathrm{PPh}_{3}$ with 7 results from attack at the phenyl substituted terminus. The ester and phenyl substituents are anticipated to lie nearly coplanar with respect to the pentadienyl ligand, thus both substituents should present roughly the same steric hin-

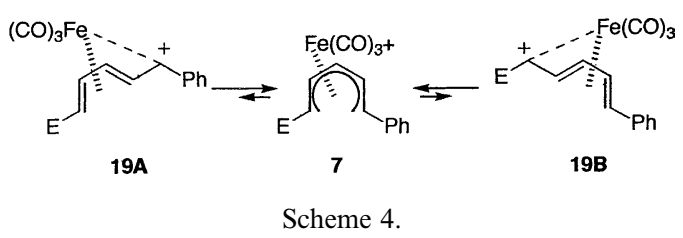


drance. Since the selectivity observed for phosphine addition cannot be attributed to steric hindrance, the selectivity may be due to the greater partial positive charge at the C5 pentadienyl carbon due to the stabilizing effect of the phenyl substituent.

Similarly, the regiochemical directing effects of the substituents present on $\mathbf{7}$ are "mismatched" for the addition of malonate nucleophiles (cf. Eqs. (1) and (2)). The products (15 or 16) from reaction of dimethyl malonate or dimethyl methylmalonate with 7 result from attack at the phenyl substituted terminus. The regioselectivity for malonate attack may be attributed to the greater partial positive charge at the $\mathrm{C} 5$ pentadienyl terminus.

To our knowledge, the formation of pentenediyl complex $\mathbf{1 8}$ is the only case of phthalimide nucleophilic attack at an internal position of a (dienyl) $\mathrm{Fe}(\mathrm{CO})_{2} \mathrm{~L}^{+}$ cation; all of the literature reactions proceed via nucleophilic attack at the dienyl terminus [5b,14]. The reason for the divergent regioselectivity observed for the reaction of 7 with phthalimide is not apparent.

\section{Experimental}

\subsection{General data}

All m.p. measurements were carried out on a MelTemp apparatus and are uncorrected. All ${ }^{1} \mathrm{H}$ and ${ }^{13} \mathrm{C}$ NMR spectra were recorded at 300 and $75 \mathrm{MHz}$, respectively, using a Varian Mercury 300+ Spectrometer. Elemental analyses were performed by Midwest Microlabs, Indianapolis, IN, or Atlantic Microlabs, Norcross, GA. High resolution mass spectra were performed at the Washington University Resource for Mass Spectrometry. Dry tetrahydrofuran (THF) and dry ether were distilled from sodium benzophenone ketyl and dry $\mathrm{CH}_{2} \mathrm{Cl}_{2}$ was distilled from $\mathrm{P}_{2} \mathrm{O}_{5}$ prior to use. All other solvents were spectral grade and were used without further purification. The term brine refers to a saturated aqueous solution of sodium chloride. Column chromatography was performed over silica gel $60(230-400$ mesh); column size was ca. $2 \mathrm{~cm} \times 35 \mathrm{~cm}$ unless otherwise noted.

\subsection{Tricarbonyl (methyl 6-hydroxy-6-phenyl-2,4-hexadie- noate) iron (9)}

To a solution of tricarbonyl(methyl 6-oxo-2,4-hexadienoate)iron $(2.00 \mathrm{~g}, 7.14 \mathrm{mmol})$ in dry THF, cooled to $-15{ }^{\circ} \mathrm{C}$ (dry ice/ $\mathrm{CH}_{3} \mathrm{CN}$ bath), was added a solution of phenylmagnesium bromide $(2.4 \mathrm{ml}, 3.0 \mathrm{M}$ in ether, 7.2 $\mathrm{mmol}$ ). After the addition was complete, the cooling bath was removed and the reaction mixture was warmed to r.t., and stirred for $5 \mathrm{~h}$. Water $(10 \mathrm{ml})$ was added, and the mixture was extracted several times with ethyl acetate. The combined extracts were dried $\left(\mathrm{MgSO}_{4}\right)$ and concen- trated. The residue was purified by column chromatography $(4 \mathrm{~cm} \times 35 \mathrm{~cm}$, hexanes-ethyl acetate $=5: 1)$ to afford 9 as a yellow solid $(2.20$ g, $86 \%)$; m.p. $107-109{ }^{\circ} \mathrm{C}$; IR (Nujol) 3390, 2063, 1999, $1712 \mathrm{~cm}^{-1} ;{ }^{1} \mathrm{H}$ NMR $\left(\mathrm{CDCl}_{3}\right) \delta 7.38-7.32(\mathrm{~m}, 4 \mathrm{H}), 5.83(\mathrm{dd}, J=5.0,8.2 \mathrm{~Hz}$, $1 \mathrm{H}), 5.63(\mathrm{dd}, J=5.0,8.5 \mathrm{~Hz}, 1 \mathrm{H}), 4.55(\mathrm{dd}, J=2.3,7.0$ $\mathrm{Hz}, 1 \mathrm{H}), 3.63(\mathrm{~s}, 3 \mathrm{H}), 2.66(\mathrm{~d}, J=2.3 \mathrm{~Hz}, \mathrm{OH}), 1.51$ (br t, $J=7.6 \mathrm{~Hz}, 1 \mathrm{H}), 1.05(\mathrm{~d}, J=8.2 \mathrm{~Hz}, 1 \mathrm{H}) ;{ }^{13} \mathrm{C} \mathrm{NMR}$ $\left(\mathrm{CDCl}_{3}\right) \delta 171.8,143.1,128.4,127.8,125.5,85.0,83.2$, 76.3, 67.3, 52.2, 46.7. Anal. Calc. for $\mathrm{C}_{16} \mathrm{H}_{14} \mathrm{O}_{6} \mathrm{Fe}: \mathrm{C}$, 53.66; H, 3.94. Found: C, 54.08; H, 3.95\%.

4.3. Tricarbonyl ( $\eta^{5}$-1-methoxycarbonyl-5-phenylpentadienyl)iron (1+) hexafluorophosphate (7)

To an ice-cold mixture of acetic anhydride $(0.46 \mathrm{ml})$ and hexafluorophosphoric acid $(0.36 \mathrm{~g}, 60 \%$ by weight $)$ was added drop-wise an ice-cold solution of dienol 9 $(0.270 \mathrm{mg}, 0.750 \mathrm{mmol})$ and acetic anhydride $(0.22 \mathrm{ml})$ in ether $(3 \mathrm{ml})$. After the addition the mixture was stirred for 30 min during which time a pale yellow precipitate appeared. The mixture was added drop-wise to excess of ether $(100 \mathrm{ml})$, and the resultant precipitate was collected by vacuum filtration. The precipitate was washed with ether and dried in vacuo to give cation $\mathbf{7}$ as a bright yellow solid (277 mg, 76\%); IR (KBr) 2118, 2080, $1792 \mathrm{~cm}^{-1} ;{ }^{1} \mathrm{H}$ NMR $\left(\mathrm{CD}_{3} \mathrm{NO}_{2}\right) \delta 7.75-7.55(\mathrm{~m}$, $5 \mathrm{H}), 7.33(\mathrm{t}, J=7.2 \mathrm{~Hz}, 1 \mathrm{H}), 6.84(\mathrm{dd}, J=7.1,13.5 \mathrm{~Hz}$, $1 \mathrm{H}), 6.76(\mathrm{dd}, J=7.3,10.6 \mathrm{~Hz}, 1 \mathrm{H}), 4.69(\mathrm{~d}, J=13.2$, $1 \mathrm{H}), 3.90$ (s, 3H), 3.13 (d, $J=10.6 \mathrm{~Hz}, 1 \mathrm{H}) ;{ }^{13} \mathrm{C} \mathrm{NMR}$ $\left(\mathrm{CD}_{3} \mathrm{NO}_{2}\right) \delta 133.8,133.1,130.8,129.1,105.5,98.5,98.1$, 94.8, 64.3, 54.7 (signals for the metal and ester carbonyls were not observed). Anal. Calc. for $\mathrm{C}_{16} \mathrm{H}_{13} \mathrm{O}_{5} \mathrm{FePF}_{6}$ : C, 39.53; H, 2.70. Found: C, 39.80; H, 2.78\%.

\subsection{Reaction of 7 with water}

To a solution of cation $7(200 \mathrm{mg}, 0.412 \mathrm{mmol})$ in $\mathrm{CH}_{2} \mathrm{Cl}_{2}(5 \mathrm{ml})$ was added water $(15 \mathrm{ml})$. The reaction mixture was stirred at r.t. for $2 \mathrm{~h}$, and then extracted several times with $\mathrm{CH}_{2} \mathrm{Cl}_{2}$. The combined extracts were dried $\left(\mathrm{MgSO}_{4}\right)$ and concentrated. The residue was purified by column chromatography (hexanes-ethyl acetate $=5: 1)$ to afford ether 10a $(15 \mathrm{mg}, 10 \%)$, followed by ether 10b (44 mg, 31\%) and finally dienol 9 (74 mg, 50\%) all as yellow oils. The spectral data for dienol 9 was identical to that previously obtained.

10a: IR (neat) 2060, 1995, $1712 \mathrm{~cm}^{-1} ;{ }^{1} \mathrm{H}$ NMR $\left(\mathrm{CDCl}_{3}\right) \delta 7.35-7.20(\mathrm{~m}, 5 \mathrm{H}), 5.80(\mathrm{dd}, J=5.0,8.1 \mathrm{~Hz}$, $1 \mathrm{H}), 5.47(\mathrm{dd}, J=5.0,8.5 \mathrm{~Hz}, 1 \mathrm{H}), 4.23(\mathrm{~d}, J=7.9 \mathrm{~Hz}$, $1 \mathrm{H}), 3.63(\mathrm{~s}, 3 \mathrm{H}), 1.46($ br t, $J=8.1 \mathrm{~Hz}, 1 \mathrm{H}), 1.04(\mathrm{~d}$, $J=8.1 \mathrm{~Hz}, 1 \mathrm{H}) ;{ }^{13} \mathrm{C}$ NMR $\left(\mathrm{CDCl}_{3}\right) \delta 172.4,141.2$, 128.9, 128.5, 126.7, 85.5, 83.9, 80.7, 65.5, 52.0, 46.6.

10b: IR (KBr) 2066, 2008, $1709 \mathrm{~cm}^{-1}$; ${ }^{1} \mathrm{H}$ NMR $\left(\mathrm{CDCl}_{3}\right) \delta 7.47-7.28(\mathrm{~m}, 5 \mathrm{H}), 5.47(\mathrm{dd}, J=5.0,8.2 \mathrm{~Hz}$, $1 \mathrm{H}), 5.24(\mathrm{dd}, J=5.0,9.1 \mathrm{~Hz}, 1 \mathrm{H}), 3.68(\mathrm{~d}, J=8.8 \mathrm{~Hz}$, 
$1 \mathrm{H}), 3.61(\mathrm{~s}, 3 \mathrm{H}), 1.45$ (br t, $J=8.5 \mathrm{~Hz}, 1 \mathrm{H}), 1.05$ (d, $J=8.1 \mathrm{~Hz}, 1 \mathrm{H}) ;{ }^{13} \mathrm{C}$ NMR $\left(\mathrm{CDCl}_{3}\right) \delta 172.5,140.3$, 129.1, 128.8, 126.8, 86.4, 84.6, 80.8, 65.4, 52.0, 46.5. Anal. Calc. for $\mathrm{C}_{32} \mathrm{H}_{26} \mathrm{O}_{11} \mathrm{Fe}_{2}$ : C, 55.05; H, 3.75. Found: C, $54.77 ; \mathrm{H}, 3.87 \%$.

\subsection{Tricarbonyl(methyl 6-phenyl-2E,4E-hexadienoate)- iron (11)}

To a suspension of cation 7 (100 $\mathrm{mg}, 0.203 \mathrm{mmol})$ in dry THF $(10 \mathrm{ml})$, cooled to $0{ }^{\circ} \mathrm{C}$, was added solid sodium cyanoborohydride $(14 \mathrm{mg}, 0.22 \mathrm{mmol})$ in one portion. The reaction mixture turned from brown to pale yellow in color. The reaction mixture was stirred at $0{ }^{\circ} \mathrm{C}$ for $1 \mathrm{~h}$, warmed to r.t. and stirred for an additional $1 \mathrm{~h}$. The mixture was poured into water $(10 \mathrm{ml})$ and extracted with ethyl acetate. The combined extracts were dried $\left(\mathrm{MgSO}_{4}\right)$ and concentrated. The residue was purified by column chromatography (hexanes-ethyl acetate $=3: 1)$ to afford $\mathbf{1 1}$ as a yellow oil $(33.2 \mathrm{mg}, 49 \%)$. The reaction of 7 with either potassium borohydride or K-selectride gave 11 (51\% and 70\%, respectively); IR (neat) $2057,1992,1701 \mathrm{~cm}^{-1} ;{ }^{1} \mathrm{H}$ NMR $\left(\mathrm{CDCl}_{3}\right) \delta 7.28$ $7.11(\mathrm{~m} .5 \mathrm{H}), 5.70(\mathrm{dd}, J=5.0,8.2 \mathrm{~Hz}, 1 \mathrm{H}), 5.28(\mathrm{dd}$, $J=5.0,8.7 \mathrm{~Hz}, 1 \mathrm{H}), 3.58(\mathrm{~s}, 3 \mathrm{H}), 2.96(\mathrm{dd}, J=7.4,14.7$ $\mathrm{Hz}, 1 \mathrm{H}), 2.80(\mathrm{dd}, J=6.6,14.7 \mathrm{~Hz}, 1 \mathrm{H}), 1.43$ (br q, $J=7.4 \mathrm{~Hz}, 1 \mathrm{H}), 0.94(\mathrm{~d}, J=8.1 \mathrm{~Hz}, 1 \mathrm{H}) ;{ }^{13} \mathrm{C} \mathrm{NMR}$ $\left(\mathrm{CDCl}_{3}\right) \delta 171.9,140.4,128.5,127.7,126.4,87.1,83.5$, 65.1, 52.1, 46.3, 40.6. FAB-HRMS $\mathrm{m} / \mathrm{z} 350.0336$ (Calc. for $\left.\mathrm{C}_{16} \mathrm{H}_{14} \mathrm{O}_{5} \mathrm{FeLi}(\mathrm{M}+\mathrm{Li}) \mathrm{m} / \mathrm{z} 350.0385\right)$.

\subsection{Tricarbonyl(methyl 6-phenyl-2E,4E,8-nonatrieno- ate)iron (12)}

To a solution of $7(150 \mathrm{mg}, 0.309 \mathrm{mmol})$ in degassed $\mathrm{CH}_{2} \mathrm{Cl}_{2}(15 \mathrm{ml})$ was added allyltrimethylsilane $(0.5 \mathrm{ml}$, $0.3 \mathrm{mmol})$. The mixture was extracted several times with $\mathrm{CH}_{2} \mathrm{Cl}_{2}$, the combined extracts were washed with brine, dried $\left(\mathrm{MgSO}_{4}\right)$ and concentrated. The residue was purified by column chromatography (hexanes-ethyl acetate $=3: 1)$ to afford 12 as a golden yellow oil $(110 \mathrm{mg}$, 93\%) which solidified upon standing in the refrigerator; mp 49-51 ${ }^{\circ} \mathrm{C}$; IR (neat) 2058, 1996, $1713 \mathrm{~cm}^{-1} ;{ }^{1} \mathrm{H}$ NMR $\left(\mathrm{CDCl}_{3}\right) \delta 7.38-7.25(\mathrm{~m}, 3 \mathrm{H}), 7.19-7.16(\mathrm{~m}, 2 \mathrm{H})$, $5.79(\mathrm{dd}, J=5.0,8.1 \mathrm{~Hz}, 1 \mathrm{H}), 5.84-5.70(\mathrm{~m}, 1 \mathrm{H}), 5.37$ $(\mathrm{dd}, J=5.0,8.8 \mathrm{~Hz}, 1 \mathrm{H}), 5.15-5.06(\mathrm{~m}, 2 \mathrm{H}), 3.64(\mathrm{~s}$, $3 \mathrm{H}), 2.55-2.49(\mathrm{~m}, 3 \mathrm{H}), 1.55-1.49(\mathrm{~m}, 1 \mathrm{H}), 1.03(\mathrm{~d}$, $J=8.1 \mathrm{~Hz}, 1 \mathrm{H}) ;{ }^{13} \mathrm{C}$ NMR $\left(\mathrm{CDCl}_{3}\right) \delta 171.9,143.7$, 135.3, 128.4, 126.5 (two signals), 116.9, 86.6, 82.9, 71.0, 52.1, 51.7, 46.1, 45.1. Anal. Calc. for $\mathrm{C}_{19} \mathrm{H}_{18} \mathrm{O}_{5} \mathrm{Fe}: \mathrm{C}$, 59.70; H, 4.76. Found: C, 59.96; H, 4.79\%.

\subsection{Reaction of 7 with excess furan}

To a solution of $7(150 \mathrm{mg}, 0.309 \mathrm{mmol})$ in degassed $\mathrm{CH}_{2} \mathrm{Cl}_{2}(20 \mathrm{ml})$ was added excess furan $(0.50 \mathrm{ml}, 6.8$ $\mathrm{mmol})$. The mixture was stirred for 15 min during which time the yellow solution turned brown in color. Water $(10 \mathrm{ml})$ was added and the mixture was extracted several times with $\mathrm{CH}_{2} \mathrm{Cl}_{2}$. The combined extracts were washed with brine, dried $\left(\mathrm{MgSO}_{4}\right)$ and concentrated. The residue was purified by column chromatography (hexanesethyl acetate $=3: 1$ ) to afford $\mathbf{1 3}$ as a golden yellow oil (90 mg, 71\%) followed by $\mathbf{1 4}(2: 1)$ as a golden yellow oil (30 mg, 3\%).

13: IR (neat) 2059, 1998, $1712 \mathrm{~cm}^{-1} ;{ }^{1} \mathrm{H}$ NMR $\left(\mathrm{CDCl}_{3}\right) \delta 7.40-7.25(\mathrm{~m}, 6 \mathrm{H}), 6.26(\mathrm{dd}, J=1.9,3.1 \mathrm{~Hz}$, $1 \mathrm{H}), 5.95(\mathrm{~d}, J=3.2 \mathrm{~Hz}, 1 \mathrm{H}), 5.83(\mathrm{dd}, J=5.0,8.2 \mathrm{~Hz}$, $1 \mathrm{H}), 5.53(\mathrm{dd}, J=5.0,8.5 \mathrm{~Hz}, 1 \mathrm{H}), 3.80(\mathrm{~d}, J=10.3$ $\mathrm{Hz}, 1 \mathrm{H}), 3.64$ (s, 3H), 1.68 (dd, $J=8.4,10.3 \mathrm{~Hz}, 1 \mathrm{H})$, $1.10(\mathrm{~d}, J=8.2 \mathrm{~Hz}, 1 \mathrm{H}) ;{ }^{13} \mathrm{C}$ NMR $\left(\mathrm{CDCl}_{3}\right) \delta 171.8$, 156.4, 141.6, 141.0, 128.5, 127.2 (two signals), 110.1, 106.0, 87.0, 83.8, 67.0, 52.2, 50.1, 46.5. FAB-HRMS $\mathrm{m} / \mathrm{z}$ 415.0440 (Calc. for $\mathrm{C}_{20} \mathrm{H}_{16} \mathrm{O}_{6} \mathrm{FeLi} \quad(\mathrm{M}+\mathrm{Li}) \mathrm{m} / \mathrm{z}$ 415.0456).

14: IR (neat) 2059, 1998, $1712 \mathrm{~cm}^{-1} ;{ }^{1} \mathrm{H}$ NMR $\left(\mathrm{CDCl}_{3}\right) \delta 7.38-7.21(\mathrm{~m}, 10 \mathrm{H}), 5.86-5.78(\mathrm{~m}, 2 \mathrm{H}), 5.81$ and $5.73(2 \mathrm{~s}, 2 \mathrm{H}), 5.58$ and $5.52(2 \mathrm{dd}, J=5.1,8.5 \mathrm{~Hz}$, $1 \mathrm{H}), 3.75$ and $3.73(2 \mathrm{~d}, J=9.9 \mathrm{~Hz}, 2 \mathrm{H}), 3.65(\mathrm{~s}, 6 \mathrm{H})$, $1.68-1.56(\mathrm{~m}, 2 \mathrm{H}), 1.10($ br d, $J=9.0 \mathrm{~Hz}, 2 \mathrm{H}) ;{ }^{13} \mathrm{C}$ NMR $\left(\mathrm{CDCl}_{3}\right) \delta 171.8,155.8,140.8,140.6,128.5,127.3$, $109.7,106.6$ [106.5], 86.9, 83.8, 66.9, 52.2, 50.2 [50.1], 46.5; diastereotopic signals in brackets.

\subsection{Reaction of 7 with dimethyl malonate anion}

To a solution of dimethyl malonate $(50 \mu \mathrm{L}, 0.64$ $\mathrm{mmol})$ in dry THF $(10 \mathrm{ml})$ at $0{ }^{\circ} \mathrm{C}$ was added, in one portion, a solution of $n-\mathrm{BuLi}(0.40 \mathrm{ml}, 1.6 \mathrm{M}$ in hexanes, $0.64 \mathrm{mmol}$ ). The mixture was stirred for $10 \mathrm{~min}$, and then solid cation 7 (259 $\mathrm{mg}, 0.532 \mathrm{mmol})$ was added in one portion. The reaction mixture was stirred at $0{ }^{\circ} \mathrm{C}$ for $1 \mathrm{~h}$, and $23^{\circ} \mathrm{C}$ for $18 \mathrm{~h}$. Water $(10 \mathrm{ml})$ was added and the mixture was extracted several times with ethyl acetate. The combined extracts were dried $\left(\mathrm{MgSO}_{4}\right)$ and concentrated, and the residue was purified by column chromatography (hexanes-ethyl acetate $=3: 1$ ) to afford 15 as a golden yellow oil (151 mg, 60\%); IR (neat) 2061, 1996, $1737 \mathrm{~cm}^{-1} ;{ }^{1} \mathrm{H}$ NMR $\left(\mathrm{CDCl}_{3}\right) \delta 7.37-7.15(\mathrm{~m}$, $5 \mathrm{H}), 6.05(\mathrm{dd}, J=5.3,8.8 \mathrm{~Hz}, 1 \mathrm{H}), 5.25(\mathrm{dd}, J=5.4$, $7.3 \mathrm{~Hz}, 1 \mathrm{H}), 3.79,3.68$, and 3.41 (3s and $\mathrm{m}, 10 \mathrm{H}$ total), $2.93(\mathrm{dd}, J=7.3,11.7 \mathrm{~Hz}, 1 \mathrm{H}), 2.79(\mathrm{dd}, J=10.2,11.7$ $\mathrm{Hz}, 1 \mathrm{H}), 2.40(\mathrm{~d}, J=8.8 \mathrm{~Hz}, 1 \mathrm{H}) ;{ }^{13} \mathrm{C} \mathrm{NMR}\left(\mathrm{CDCl}_{3}\right) \delta$ 172.3, 167.3, 166.3, 140.8, 128.5, 127.5, 127.2, 94.2, 84.2, $62.2,61.7,53.2,52.8,52.3,46.5,45.1$. FAB-HRMS $\mathrm{m} / \mathrm{z}$ 479.0594 (Calc. for $\mathrm{C}_{21} \mathrm{H}_{20} \mathrm{O}_{9} \mathrm{FeLi} \quad(\mathrm{M}+\mathrm{Li}) \mathrm{m} / \mathrm{z}$ 479.0617).

\subsection{Reaction of 7 with dimethyl methylmalonate anion}

To a solution of sodium dimethyl methylmalonate (0.331 mmol, freshly prepared from dimethyl malonate 
and excess sodium hydride) in dry THF $(15 \mathrm{ml})$ was added, in one portion, solid cation $7(150 \mathrm{mg}, 0.309$ mmol). The reaction mixture was stirred at $0{ }^{\circ} \mathrm{C}$ for $1 \mathrm{~h}$, and then poured into brine. The mixture was extracted several times with ethyl acetate, and the combined extracts were dried $\left(\mathrm{MgSO}_{4}\right)$ and concentrated. The residue was purified by column chromatography (hexanesethyl acetate $=3: 1$ ) to afford $\mathbf{1 6}$ as a golden yellow oil (91 mg, 61\%); IR (neat) 2061, 1999, $1716 \mathrm{~cm}^{-1} ;{ }^{1} \mathrm{H}$ NMR $\left(\mathrm{CDCl}_{3}\right) \delta 7.33-7.16(\mathrm{~m}, 5 \mathrm{H}), 6.05(\mathrm{dd}, J=5.2$, $8.4 \mathrm{~Hz}, 1 \mathrm{H}), 5.28(\mathrm{dd}, J=5.2,7.7 \mathrm{~Hz}, 1 \mathrm{H}), 3.72,3.66$, and $3.59(3 \mathrm{~s}, 9 \mathrm{H}$ total $), 3.34(\mathrm{dd}, J=7.7,12.4 \mathrm{~Hz}, 1 \mathrm{H})$, $2.90(\mathrm{~d}, J=12.4 \mathrm{~Hz}, 1 \mathrm{H}), 2.36(\mathrm{~d}, J=8.4 \mathrm{~Hz}, 1 \mathrm{H}), 1.40$ $(\mathrm{s}, 3 \mathrm{H}) ;{ }^{13} \mathrm{C}$ NMR $\left(\mathrm{CDCl}_{3}\right) \delta 172.4,170.3,170.2,139.7$, $128.9,128.0,127.4,93.9,85.3,61.1,60.7,52.9,52.8$, 52.2, 49.1, 46.4, 18.7. FAB-HRMS $\mathrm{m} / \mathrm{z} 493.0762$ (Calc. for $\mathrm{C}_{22} \mathrm{H}_{22} \mathrm{O}_{9} \mathrm{FeLi}(\mathrm{M}+\mathrm{Li}) \mathrm{m} / \mathrm{z}$ 493.0773).

\subsection{Reaction of 7 with triphenylphosphine}

To a solution of cation $7(150 \mathrm{mg}, 0.309 \mathrm{mmol})$ in $\mathrm{CH}_{2} \mathrm{Cl}_{2}(20 \mathrm{ml})$ was added solid triphenylphosphine (81 $\mathrm{mg}, 0.31 \mathrm{mmol})$. The reaction mixture was stirred for 20 min, during which time the bright yellow color became a pale yellow. The reaction mixture was concentrated and triturated with ether just until it becomes cloudy. After standing, a precipitate formed which was collected by vacuum filtration, and the crystals washed with additional ether and dried in vacuo to afford $\mathbf{1 7}$ as a golden yellow solid (215 mg, 93\%); m.p. 163-165 ${ }^{\circ} \mathrm{C}$ (dec.); IR (KBr) 2067, 2012, $1716 \mathrm{~cm}^{-1} ;{ }^{1} \mathrm{H}$ NMR $\left(\mathrm{CD}_{3} \mathrm{CN}\right) \delta 7.90$ (br t, $J=6.6 \mathrm{~Hz}, 3 \mathrm{H}), 7.72-7.66(\mathrm{~m}, 6 \mathrm{H}), 7.54-7.43(\mathrm{~m}$, $7 \mathrm{H}), 7.37(\mathrm{t}, J=7.6 \mathrm{~Hz}, 2 \mathrm{H}), 6.90($ br d, $J=7.2 \mathrm{~Hz}$, $2 \mathrm{H}), 6.04$ (dd, $J=5.3,8.8 \mathrm{~Hz}, 1 \mathrm{H}$ ), 5.37 (br t, $J=5.9$ $\mathrm{Hz}, 1 \mathrm{H}), 4.03(\mathrm{dd}, J=12.9,15.2 \mathrm{~Hz}, 1 \mathrm{H}), 3.68(\mathrm{~s}, 3 \mathrm{H}$ total), 3.09 (dt, $J=7.1,12.9 \mathrm{~Hz}, 1 \mathrm{H}), 2.57$ (d, $J=9.1$ $\mathrm{Hz}, 1 \mathrm{H}) ;{ }^{13} \mathrm{C}$ NMR $\left(\mathrm{CD}_{3} \mathrm{CN}\right) \delta 172.9,135.0(\mathrm{~d}$, $\left.J_{\mathrm{PC}}=3.0 \mathrm{~Hz}\right), 134.9\left(\mathrm{~d}, J_{\mathrm{PC}}=9.8 \mathrm{~Hz}\right), 133.5(\mathrm{~d}$, $\left.J_{\mathrm{PC}}=4.0 \mathrm{~Hz}\right), 129.9,129.7,129.6,129.1\left(\mathrm{~d}, J_{\mathrm{PC}}=2.3\right.$ $\mathrm{Hz}), 117.5\left(\mathrm{~d}, J_{\mathrm{PC}}=79.6 \mathrm{~Hz}\right), 96.5,86.2,54.2(\mathrm{~d}$, $\left.J_{\mathrm{PC}}=7.4 \mathrm{~Hz}\right), 53.3,48.5,44.4\left(\mathrm{~d}, J_{\mathrm{PC}}=33.2 \mathrm{~Hz}\right)$. Anal. Calc. for $\mathrm{C}_{34} \mathrm{H}_{28} \mathrm{O}_{5} \mathrm{FeP}_{2} \mathrm{~F}_{6}: 0.5 \mathrm{H}_{2} \mathrm{O}: \mathrm{C}, 53.91 ; \mathrm{H}, 3.86$. Found: C, 53.85; H, 3.78\%.

\subsection{Reaction of 7 with potassium phthalimide}

To a solution of cation $7(150 \mathrm{mg}, 0.309 \mathrm{mmol})$ in degassed $\mathrm{CH}_{2} \mathrm{Cl}_{2}(15 \mathrm{ml})$ was added solid potassium phthalimide ( $86 \mathrm{mg}, 0.46 \mathrm{mmol})$. The mixture was stirred for $30 \mathrm{~min}$ and then water $(10 \mathrm{ml})$ was added and the mixture was stirred an additional $5 \mathrm{~min}$. The mixture was extracted several times with $\mathrm{CH}_{2} \mathrm{Cl}_{2}$, the combined extracts were washed with brine followed by water, dried $\left(\mathrm{MgSO}_{4}\right)$ and concentrated. The residue was purified by column chromatography (hexanes-ethyl acetate $=5: 1 \rightarrow 3: 1$ gradient) to afford $\mathbf{1 8}$ as a bright yellow crystalline solid (110 mg, 73\%); m.p. $100-102{ }^{\circ} \mathrm{C}$; IR (KBr) 2065, 1994, 1772, $1713 \mathrm{~cm}^{-1} ;{ }^{1} \mathrm{H}$ NMR $\left(\mathrm{CDCl}_{3}\right) \delta$ 7.76-7.73 (m, 2H), 7.67-7.64 (m, 2H), 7.53-7.50 (m, $2 \mathrm{H}), 7.38-7.25(\mathrm{~m}, 3 \mathrm{H}), 5.62(\mathrm{dd}, J=7.3,9.9 \mathrm{~Hz}, 1 \mathrm{H})$, $5.52-5.41(\mathrm{~m}, 2 \mathrm{H}), 4.58(\mathrm{dd}, J=6.2,7.3 \mathrm{~Hz}, 1 \mathrm{H}), 3.69$ (s, 3H), $1.99(\mathrm{~d}, J=9.9 \mathrm{~Hz}, 1 \mathrm{H}) ;{ }^{13} \mathrm{C}$ NMR $\left(\mathrm{CDCl}_{3}\right) \delta$ 208.9, 207.8, 202.6, 178.1, 167.1, 138.7, 133.8, 131.2, 128.9, 127.6, 125.8, 123.1, 96.4, 58.0, 52.1, 48.3, 17.4 (signal for $\mathrm{C} 5$ obscured by $\mathrm{CDCl}_{3}$ signals). Anal. Calc. for $\mathrm{C}_{24} \mathrm{H}_{17} \mathrm{NO}_{7} \mathrm{Fe}: \mathrm{C}, 59.16 ; \mathrm{H}, 3.52 ; \mathrm{N}, 2.87$. Found: $\mathrm{C}$, $59.85 ; \mathrm{H}, 3.61 ; \mathrm{N}, 2.75 \%$.

\subsection{X-ray structural determination of $\mathbf{1 8}$}

Golden yellow crystals of $\mathbf{1 8}$ were grown from $\mathrm{CH}_{2} \mathrm{Cl}_{2}$ /hexanes. A crystal $\left(0.43 \times 0.43 \times 0.40 \mathrm{~mm}^{3}\right)$ was attached to a glass fiber and mounted on a Brucker P4 diffractometer. The data were collected at $298 \mathrm{~K}$ using graphite monochromatized Mo $\mathrm{K} \alpha$ radiation ( $\lambda=0.71073 \AA)$ and the $\Theta / 2 \Theta$ mode in the $\Theta$ range 2.04 to $24.99^{\circ}$. No absorption correction was used. The structure was solved by direct methods and refined by full-matrix least squares based on $F^{2}$ [15]. A total of 4883 reflections were collected (3831 independent reflections, $R_{\text {int }}=0.0244$ ).

\section{Supplementary material}

Crystallographic data for the structural analysis has been deposited with the Cambridge Crystallographic Data Centre, CCDC No. 221734. Copies of this information may be obtained free of charge from The Director, CCDC, 12 Union Road, Cambridge, CB2 1EZ, UK (fax: +44-1223-336033; deposit@ccdc.cam.ac.uk).

\section{Acknowledgements}

Financial support for this work was provided by the National Institutes of Health (GM-42641). High-resolution mass-spectral determinations were made at the Washington University Mass Spectrometry Resource, an NIH Research Resource (Grant No. P41RR0954).

\section{References}

[1] J.E. Mahler, D.H. Gibson, R. Pettit, J. Am. Chem. Soc. 85 (1963) 3959.

[2] (a) L. Motiei, I. Marek, H.E. Gottlieb, V. Marks, J.-P. Lellouche, Tetrahedron Lett. 44 (2003) 5909;

(b) S. Li, W.A. Donaldson, Synthesis (2003) 2064.

[3] W.A. Donaldson, L. Shang, M. Ramaswamy, C.A. Droste, C. Tao, D.W. Bennett, Organometallics 14 (1995) 5119. 
[4] (a) W.A. Donaldson, L. Shang, C. Tao, Y.K. Yun, M. Ramaswamy, V.G. Young Jr., J. Organomet. Chem. 539 (1997) 87; (b) Y.K. Yun, K. Godula, Y. Cao, W.A. Donaldson, J. Org. Chem. 68 (2003) 901.

[5] For a compilation of references up to 1997 see (a) W.A. Donaldson, Aldrichim. Acta 30 (1997) 17;

(b) Y.K. Yun, H. Bärmann, W.A. Donaldson, Organometallics 20 (2001) 2409;

(c) M.A. Hossain, M.J. Jin, W.A. Donaldson, J. Organomet. Chem. 630 (2001) 5.

[6] (a) J.A.S. Howell, A.G. Bell, P.J. O'Leary, G.R. Stephenson, M. Hastings, P.W. Howard, D.A. Owen, A.J. Whitehead, P. McArdle, D. Cunningham, Organometallics 15 (1996) 4247;

(b) D. Enders, B. Jandeleit, S. von Berg, J. Organomet. Chem. 533 (1997) 219-236;

(c) G.M. Williams, D.E. Rudisill, Inorg. Chem. 28 (1989) 797;

(d) P. McArdle, H. Sherlock, J. Chem. Soc., Dalton Trans. (1978) 1678;

(e) T.G. Bonner, K.A. Holder, P. Powell, E. Styles, J. Organomet. Chem. 131 (1977) 105.

[7] M. Labassi, R. Grée, Bull. Soc. Chim. Fr. 129 (1992) 151.

[8] C. Tao, W.A. Donaldson, J. Org. Chem. 58 (1993) 2134.

[9] (a) P. Pinsard, J.-P. Lellouche, J.-P. Beaucourt, L. Toupet, L. Schio, R. Grée, J. Organomet. Chem. 371 (1989) 219;

(b) J.A.S. Howell, A.G. Bell, P.J. O'Leary, G.R. Stephenson, M. Hastings, P.W. Howard, D.A. Owen, A.J. Whitehead, P. McArdle, D. Cunningham, Organometallics 15 (1996) 4247;

(c) J.R. Bleeke, M.K. Hays, Organometallics 6 (1987) 1367; (d) J.R. Bleeke, R.J. Wittenbrink, T.W. Clayton Jr., M.Y. Chiang, J. Am. Chem. Soc. 112 (1990) 6539;

(e) S.P. Saber, A.M. Slawin, S.E. Thomas, D.J. Williams, M.F. Ward, P.A. Worthington, J. Chem. Soc., Chem. Commun. (1994) 2169 ;

(f) S.E. Gibson, S.P. Saberi, A.M.Z. Slawin, P.D. Stanley, M.F. Ward, D.J. Williams, P. Worthington, J. Chem. Soc., Perkin Trans. 1 (1995) 2147.

[10] T.S. Sorenson, C.R. Jablonski, J. Organomet. Chem. 25 (1970) C62.

[11] R.S. Bayoud, E.R. Biehl, P.C. Reeves, J. Organomet. Chem. 150 (1978) 75

[12] Formation of ethers from the reaction of other (pentadienyl)iron cations with water has previously been observed W.A. Donaldson, P.T. Bell, M.-J. Jin, J. Organomet. Chem. 441 (1992) 449.

[13] (a) A. Salzer, A. Hafner, Helv. Chim. Acta 66 (1983) 1174;

(b) U. Englert, B. Ganter, M. Kaser, E. Klinkhammer, T. Wagner, A. Salzer, Chem. Eur. J. 2 (1996) 143.

[14] (a) A.J. Birch, A.J. Liepa, G.R. Stephenson, Tetrahedron Lett. (1979) 3565;

(b) A.J. Birch, A.J. Liepa, G.R. Stephenson, J. Chem. Soc., Perkin Trans. 1 (1982) 713;

(c) A.J. Pearson, M.P. Burello, J. Chem. Soc., Chem. Commun. (1989) 1332;

(d) N. Wallock, W.A. Donaldson, Tetrahedron Lett. 43 (2002) 4541.

[15] G.M. Sheldrick, shelx 97, Program for Crystal Structure Refinement, University of Göttingen, Germany, 1997. 